JKKP : Jurnal Kesejahteraan Keluarga dan Pendidikan

http://doi.org/10.21009/JKKP

DOI: doi.org/10.21009/JKKP.061.02

E-ISSN : 2597-4521

\title{
PENGEMBANGAN MODUL PERAWATAN KESEHATAN MENTAL BERBASIS HOME CARE
}

\author{
1,a) Tati, ${ }^{1, b)}$ Yoyoh Jubaedah, dan 1,c) Ayu Khairunnissa Yusup \\ Email : a) tatiabas@upi.edu, ${ }^{\text {b) }}$ yoyohjubaedah@upi.edu, ${ }^{\text {c) }}$ ayukhairunnissa1@gmail.com \\ ${ }^{1}$ Prodi Pendidikan Kesejahteraan Keluarga, Universitas Pendidikan Indonesia JI. Dr. \\ Setiabudhi No. 229 Bandung 40154 Jawa Barat-Indonesia, Telp. 022-2013163 Fax. 022- \\ 2013651,Email:prodi-pkk@upi.edu
}

\begin{abstract}
Abstrak
Tujuan dari penelitian ini yaitu untuk menghasilkan Modul Pendampingan Lanjut Usia Berbasis Home care dalam Perawatan Kesehatan Mental. Metode yang digunakan yaitu Research and Development dengan pendekatan ADDIE. Pengembangan modul dilakukan melalui validasi expert judgment oleh ahli untuk menilai kelayakan modul yang telah dirancang. Aspek yang dinilai dalam validasi adalah aspek kelayakan isi dan kelayakan modul. Hasil akhir dari validasi yang dilakukan oleh ahli di bidang pelayanan lansia dan ahli di bidang modul adalah Modul Pendampingan Lanjut Usia Berbasis Home care dalam Perawatan Kesehatan Mental dinyatakan sangat layak untuk digunakan atau diimplementasikan. Rekomendasi dari peneitian ini ditunjukkan bagi pendamping, diharapkan dapat digunakan sebagai bahan belajar dan bahan acuan dalam proses pendampingan lanjut usia berbasis Home care dalam perawatan kesehatan mental. Bagi peneliti selanjutnya, diharapkan penelitian dapat dilanjutkan pada tahap implementasi dapat dilakukan pada anggota keluarga yang menjadi pendamping lanjut usia di rumah
\end{abstract}

Kata Kunci: Modul, Pendampingan, Lanjut Usia, Perawatan Kesehatan Mental

\section{Development of Mental Health Nursing Care Module with Home Care Based}

\begin{abstract}
The purpose of this study was to produce a Home care Based Mental Health Nursing Care Module. The method used was Research and Development with the ADDIE approach. However, the research was only carried out until the development stage. Modules were designed using expert judgment validation by experts to assess the feasibility of the modules that have been designed. The aspects assessed in the validation are aspects of the feasibility of the content and feasibility of the module. The final result of the validation carried out by experts in the field of elderly services and experts in the field of modules/media is the Home care Mental Health Care Mentoring Module Based on Home care stated that it is very feasible to use or implement. Recommendations of this research are shown to assistants, expected to be used as learning materials and reference materials in the Home care mental health care mentoring process. For further researchers, it is expected that research can be continued at the implementation stage can be carried out on family members who are elderly assistants at home.
\end{abstract}




\section{PENDAHULUAN}

Keluarga sejahtera dan bahagia merupakan harapan setiap individu yang harus terpenuhi kebutuhan fisik dan psikisnya secara seimbang. Begitupun lansia yang merupakan bagian dari keluarga, mendambakan perhatian dan perawatan di dalam memenuhi kebutuhan dalam kehidupan sehari-hari. Pada kenyataannya di masyarakat masih banyak lanjut usia non potensial yang bermasalah dan tidak percaya diri di dalam menjalankan kehidupannya.

Keluarga memiliki peranan yang sangat penting untuk dapat mengembalikan kepercayaan lanjut usia agar merasa masih dibutuhkan dan mampu berdayaguna, baik di lingkungan keluarga maupun dalam hidup bermasyarakat, sehingga akan menjalani sisa hidup untuk dapat mencapai kesejahteraan lahir dan batin. (Widyakusuma, 2013).

Peningkatan jumlah lanjut usia akan membawa dampak terhadap berbagai aspek kehidupan, karena secara alamiah lanjut usia mengalami penurunan baik dari segi fisik, mental, spiritual dan psikososial, selain itu para lanjut usia mulai kehilangan pekerjaan, tujuan hidup, teman, terkena risiko penyakit, tidak dapat beradaptasi dengan lingkungan, dan kesepian. Penurunan-penurunan yang terjadi pada lanjut usia dapat memicu terjadinya gangguan kesehatan mental (Riani, Adi, \& Supriyono, 2010).

Gangguan kesehatan mental yang sering muncul pada masa ini adalah depresi, gangguan intelektual, dan fobia. Faktor yang menyebabkan gangguan kesehatan mental lanjut usia yaitu hilangnya peranan sosial, kematian teman atau sanak saudaranya, penurunan kesehatan, hilangnya interaksi sosial, keterbatasan finansial, dan penurunan fungsi intelektual (Kusumowardani \& Puspitosari, 2010). Oleh karena itu lanjut usia perlu perhatian dan dukungan dari keluarga maupun dari masyarakat sekitar agar dapat mengatasi perubahan keadaan fisik dan keadaan mental yang makin rentan. Dukungan berupa perawatan kesehatan mental lanjut usia merupakan bentuk bantuan atau bimbingan, pengawasan, perlindungan dan pertolongan untuk lansia (Azizah, 2011).

(Kusumowardani \& Puspitosari, 2010). Oleh karena itu lanjut usia perlu perhatian dan dukungan dari keluarga maupun dari masyarakat sekitar agar dapat mengatasi perubahan keadaan fisik dan keadaan mental yang makin rentan. Dukungan berupa perawatan kesehatan mental lanjut usia merupakan bentuk bantuan atau bimbingan, pengawasan, perlindungan dan pertolongan untuk lansia (Azizah, 2011).

Masalah-masalah yang dihadapi lanjut usia menurut Peraturan Menteri Sosial RI (dalam Nurfatimah, Rifa'i, \& Jubaedah, 2017) pada proses penuaannya membuat lanjut usia membutuhkan pelayanan dari berbagai pihak. Penanganan secara komprehensif sebagai upaya untuk meningkatkan kesejahteraan sosial bagi lanjut usia. Upaya peningkatan kesejahteraan sosial lanjut usia menurut PP Nomor 43 tahun 2004 adalah serangkaian kegiatan yang dilaksanakan secara terkoordinasi antara pemerintah dan masyarakat yang memberdayakan lanjut usia, agar lanjut usia tetap dapat melaksanakan fungsi sosial dan berperan aktif secara wajar dalam hidup bermasyarakat, berbangsa, dan bernegara. Upaya peningkatan kesejahteraan sosial lanjut usia dapat dilaksanakan melalui bentuk pelayanan sosial lanjut usia baik dalam panti maupun luar panti.

Program pelayanan sosial di luar panti berupa pendampingan berbasis home care bagi lanjut usia di Posbindu sangat besar manfaatnya terhadap pemenuhan kebutuhan lanjut usia melalui pendampingan dengan melibatkan keluarga lanjut usia, Posbindu dan lingkungan masyarakat (Nurfatimah et al., 2017). Home care merupakan pelayanan yang lengkap karena dapat memberikan pemenuhan kebutuhan dasar, kebutuhan sehari- hari, pendampingan dan pelayanan melibatkan anggota keluarga di rumah.

Penelitian ini merupakan penelitian payung yang merujuk pada penelitian "Model Pendampingan Lanjut Usia Berbasis Home care dalam Implementasi Pendidikan Vokasional" oleh Tati, dkk (2017) yang menyatakan bahwa home care adalah pelayanan lanjut usia yang belum mendapatkan pelayanan, dengan memberikan kebutuhan dan perawatan lanjut usia, serta mengutamakan peran keluarga dan masyarakat. Bentuk program pendampingan lanjut usia pada aspek mental terbagi menjadi tiga bagian, yaitu kecerdasan intelektual, kecerdasan emosional dan kecerdasan moral.

Studi pendahulan yang dilakukan dengan wawacara kepada kader posbindu, diperoleh hasil 
bahwa terdapat program pendampingan lanjut usia berbasis home care yang terdiri dari aspek fisik, aspek sosial, aspek mental dan aspek spiritual. Program di posbindu belum memiliki sumber belajar berupa modul secara khusus tentang perawatan kesehatan mental lanjut usia.

Modul merupakan bahan ajar cetak yang dirancang untuk dapat dipelajari secara mandiri oleh peserta pembelajaran. Modul disebut juga media untuk belajar mandiri karena di dalamnya telah dilengkapi petunjuk untuk belajar sendiri. Artinya, pembaca dapat melakukan kegiatan belajar tanpa kehadiran pengajar secara langsung (Departemen Pendidikan Nasional, 2008). Parmin \& Peniati (2012) menyatakan tentang pentingnya modul yaitu modul dapat diterapkan pada kehidupan seharihari, dengan sajian modul yang memberikan ilustrasi, dilengkapi gambar dan penjelasan dari temuan para peneliti.

Tidak adanya panduan pada program pendampingan lanjut usia berbasis home care menyebabkan kesulitan dalam mendampingi lanjut usia, seperti pada saat lansia cemas pendamping kebingungan untuk mengatasinya. Sehingga dibutuhkan suatu panduan berupa modul sebagai alat bantu pendamping dalam merawat kesehatan mental lanjut usia. Modul perawatan kesehatan mental lansia merupakan bahan ajar yang dirancang secara sistematis yang memuat satu ranah dari materi perawatan kesehatan mental lansia, yang dapat memudahkan pendamping lansia untuk belajar secara mandiri dalam melakukan pendampingan.

\section{METODOLOGI PENELITIAN}

Metode yang digunakan dalam penelitian ini adalah Research and Development. Tahapan yang dilakukan diawali dengan menganalisi kebutuhan dalam perancangan hingga tahap pengembangan modul pendampingan lanjut usia berbasis home care dalam perawatan kesehatan mental. Uji kelayakan modul dilakukan melalui Expert Judgment.

Instrumen penelitian yang digunakan dalam penelitian ini yaitu pedoman wawancara dan lembar validasi. Prosedur penelitian adalah tahap kegiatan untuk menyelesaikan penelitian. Langkah-langkah dalam penelitian ini yaitu tahap persiapan, tahap pelaksanaan, dan tahap penyelesaian.

\section{HASIL DAN PEMBAHASAN}

\section{A. Temuan}

Temuan pada penelitian ini mengacu pada data yang diperoleh melalui hasil wawancara dan expert judgment. Pembahasan yang akan diuraikan pada temuan penelitian ini yaitu terdiri dari data analisis kebutuhan modul, perancangan modul, hasil validasi modul dan menghasilkan modul pendampingan perawatan kesehatan mental lanjut usia berbasis home care.

\section{Analisis Kebutuhan Modul Pendampingan Lanjut Usia Berbasis Home care dalam Perawatan Kesehatan Mental}

Analisis kebutuhan perancangan modul pendampingan Lanjut Usia Berbasis Home care dalam perawatan kesehatan mental, diperoleh dari hasil wawancara. Tujuan dari wawancara ini yaitu untuk menggali data tentang ketersediaan modul pendampingan perawatan kesehatan mental, serta kegiatan pendampingan yang berada dil ingkungan keluarga di Kelurahan Gegerkalong yang akan dijadikan bahan rujukan dalam perancangan modul pendampingan Lanjut Usia Berbasis Home care dalam perawatan kesehatan mental.

Bentuk bimbingan yang dilakukan kader kepada pendamping lansia yaitu dengan memberikan informasi terkait keluhan yang pendamping rasakan seperti bagaimana pada saat lansia yang terkena penyakit struk, lansia yang tidak ingin makan dan lain sebagainya, lalu kader memberikan arah bahwa pendamping harus selalu membimbing, mengingatkan, dan menyemangati lansia dalam setiap kegiatan apapun, serta kader selalu mengingatkan agar pendamping selalu mengajak dan mengingatkan lansia untuk selalu beribadah.

Semua informasi yang kader sampaikan kepada pendamping selama ini hanya mengandalkan pengetahuan yang kader punya dari membaca di media internet dan dari keahlian kader yang di 
tekuni (seperti memijat dan refleksi), tidak adanya sumber bacaan atau modul tentang perawatan kesehatan mental lanjut usia yang tersedia baik buku dari pemerintah maupun buku khusus tentang mental lanjut usia yang kader miliki. Pendamping di rumah yang berada lingkungan keluarga di RW 08 juga tidak memiliki sumber bacaan khusus tentang pendampingan perawatan kesehatan mental lanjut usia

Pada saat menanyakan terkait akan dirancangnya modul pendampingan lanjut usia berbasis home care dalam perawatan kesehatan, pihak keluarga lansia sangat mendukung dan senang, karena dengan adanya modul yang akan dirancang membuat pendamping yang ada di rumah lebih mengerti dan memahami bagaimana cara mendampingi lansia di rumah khususnya dalam perawatan kesehatan mental lanjut usia. Pada saat menanyakan terkait materi yang diperlukan sesuai dengan kebutuhan pendamping yang ada di rumah, menyarankan agar terdapat senam, permainan yang menyenangkan, tentang beribadah dan pembahasan dikemas secara sederhana dan menarik. Pada saat menanyakan tentang metode yang cocok untuk pendamping di rumah yaitu dengan bimbingan, ajakan dan mengingatkan, serta hambatan dalam pendampingan menyatakan bahwa waktu yang sangat kurang dikarenakan semua pendamping lansia bekerja dan lansianya juga masih memiliki pekerjaan yang dilakukan.

Analisis yang dapat disimpulkan yaitu pendamping yang ada di rumah memerlukan buku atau modul yang dapat memberikan pemahaman dan sebagai sumber acuan dalam melaksanakan pendampingan, khususnya dalam pendampingan perawatan kesehatan mental lanjut usia berbasis home care. Materi yang di butuhkan yaitu tentang senam, permainan dan dikemas secara sederhana serta menarik untuk dibaca. Metode yang cocok digunakan bagi pendamping yang ada di rumah yaitu bimbingan, ajakan dan mengingatkan, serta hambatan yang dihadapi pendamping di rumah yaitu waktu yang sangat kurang.

Berdasarkan analisis yang telah dilakukan kemudian dijadikan petimbangan dalam penyusunan modul pendampingan perawatan kesehatan mental lanjut usia berbasis home care, seperti dirancang sesederhana dan semenarik mungkin, materi, dan metode disesuaikan dengan kebutuhan pendamping.

\section{Merancang Modul Pendampingan Lanjut Usia Berbasis Home care Dalam Perawatan Kesehatan Mental}

Merancang modul pendampingan lanjut usia berbasis home care dalam perawatan kesehatan mental bertujuan agar pendamping memahami bahwa dalam pendampingan memerlukan pengetahuan dan langkah-langkah yang harus dilakukan secara terarah. Merancang modul pendampingan lanjut usia berbasis home care dalam perawatan kesehatan mental dibuat dengan bahasa yang mudah dimengerti serta dipahami pendamping dan dirancang dengan menarik agar tidak membuat pendamping bosan dalam membaca.

Perancangan modul pendampingan perawatan kesehatan mental lanjut usia berbasis home care terdiri dari tiga bagian yaitu, pembuka, isi dan penutup. Bagian pembuka terdiri dari cover, kata pengantar, dan daftar isi. Bagian isi terdiri dari deskripsi ringkasan, tujuan, pokok bahasan, proses pendampingan, metode pendampingan, prinsip pendampingan, alat bantu dan evaluasi pendampingan. Bagian penutup terdiri dari rangkuman dan daftar pustaka.

\section{Validasi Pengembangan Modul Pendampingan Lansia Berbasis Home care}

Validasi dilakukan melalui expert judgment untuk diberi penilaian oleh ahli/validator, agar diketahui apakah modul yang telah dirancang layak atau tidak layak untuk digunakan. Validator yang memvalidasi modul ini yaitu 1 orang ahli modul dan 1 orang ahli bidang pelayanan lansia, tetapi pada saat validasi hanya dilakukan pada satu orang dikarenakan validator tersebut merupakan ahli dalam bidang keduanya.

\section{a. Hasil validasi oleh ahli modul}

Modul ini dirancang dan dikonsultasikan dengan menggunakan format expert judgment kepada ahli modul/media untuk mendapatkan penilaian dan saran perbaikan agar layak untuk di implementasikan. 
Aspek kelayakan modul terdapat tiga aspek indikator penilaian yaitu kesesuaian bagian pembuka, isi dan penutup.

Hasil validasi modul pendampingan dukungan sosial pada aspek kelayakan modul terdiri dari tiga indikator penilaian yaitu bagian pembuka, bagian isi, dan bagian penutup. Kriteria bagian pembuka modul mendapatkan rata-rata persentase sebesar $100 \%$. Kriteria bagian isi mendapatkan rata-rata persentase $100 \%$, dan bagian penutup mendapatkan rata-rata persentase sebesar $100 \%$. Secara keseluruhan, aspek kelayakan isi modul mendapatkan rata-rata persentase sebesar $100 \%$, yang berarti perancangan modul pendampingan perawatan kesehatan mental lanjut usia berbasis home care sangat layak untuk diimplementasikan.

\section{b. Hasil validasi oleh ahli pelayanan lansia}

Hasil validasi yang dilakukan oleh ahli pelayanan lansia memuat aspek kelayakan isi. Hasil validasi modul pendampingan perawatan kesehatan mental lanjut usia berbasis home care yang dilakukan oleh ahli pelayanan lansia secara keseluruhan mendapatkan rata-rata persentase sebesar $100 \%$, yang berarti perancangan modul pendampingan perawatan kesehatan mental lanjut usia berbasis home care dinyatakan sangat layak untuk digunakan.

\section{B. PEMBAHASAN}

Pembahasan pada penelitian ini terdiri dari tiga bagian, yaitu; (1) Pembahasan analisis kebutuhan perancangan modul, (2) Pembahasan perancangan modul, (3) Pembahasan hasil validasi pengembangan modul.

Bahan acuan pendampingan sangat dibutuhkan karena agar pendamping tepat dalam memberikan perawatan kepada lansia. Bentuk pendampingan yang dilakukan hanya berupa bimbingan, mengingatkan, dan menyemangati. Kementrian Sosial RI (2014) mengemukakan bahwa bentuk pendampingan untuk lansia yaitu berupa ajakan, bimbingan dan mengingatkan lansia dalam menunjang pelayanan kepada lansia.

Proses pendampingan yang dilakukan didapat dari internet dan dari buku lansia yang bersifat umum, sehingga pendamping lansia menyatakan bahwa kebingungan dalam proses pendampingan. Bahan acuan dalampendampingan dapat menggunakan modul, karena Modul merupakan bahan ajar cetak yang dirancang untuk dapat dipelajari secara mandiri oleh pendamping. Modul disebut juga media untuk belajar mandiri karena di dalamnya telah dilengkapi petunjuk untuk belajar sendiri. Artinya, pendamping dapat melakukan kegiatan pendampingan tanpa kehadiran pengajar secara langsung (Departemen Pendidikan Nasional, 2008).

Pihak keluarga sangat mendukung dengan dirancangnya modul pendampingan perawatan kesehatan mental lanjut usia berbasis home care, karena agar pendamping yang ada di rumah dapat mengetahu cara pendampingan yang tepat. Selain itu, adanya modul yang akan dirancang membuat pendamping yang ada di rumah akan menambah pengetahuan lebih dan memahami cara mendampingi lansia di rumah khususnya dalam perawatan kesehatan mental lanjut usia. Parmin \& Peniati (2012) menyatakan tentang pentingnya modul yaitu modul dapat diterapkan pada kehidupan sehari-hari, dengan sajian modul yang memberikan ilustrasi, dilengkapi gambar dan penjelasan dari temuan para peneliti.

Merancang modul pendampingan perawatan kesehatan mental lanjut usia berbasis home care dilakukan setelah analisis kebutuhan, dalam merancang modul terdiri dari tiga bagian yaitu bagian pembuka, isi dan penutup yang merujuk pada komponen-komponen penulisan modul yang bersumber dari Kementerian Sosial RI, 2014, yang selanjutnya disesuaikan dengan kebutuhan modul yang dibuat.

Perancangan bagian pembuka yaitu perancangan yang pertama membuat desain cover. Cover dibuat dengan tampilan warna latar yang tidak mencolok, tetapi pada warna latar judul di buat warna yang terang agar judul terlihat jelas dan fokus utama yang terlihat. Judul yang ditulis dengan ukuran yang lebih besar dari tulisan lainnya seperti tempat pembuatan modul, tahun pembuatan modul dan identitas dikarenakan untuk mempertegas judul utama dari modul, serta judul dibuat semenarik mungkin seperti latar dan bentuk yang digunakan, dan kata yang digunakan yang dapat dipahami oleh 
pendamping. Hal ini selaras dengan Departemen Pendidikan Nasional (2008) bahwa judul modul perlu menarik, dan memberi gambaran tentang materi yang dibahas. Pada cover juga terdapat gambar, tempat pembuatan modul, tahun pembuatan dan identitas modul. Perancangan yang kedua membuat kata pengantar, kata pengantar berisikan ucapan syukur, dan gambaran tentang tujuan dari dibuatnya modul. Rahdiyanta (2009) memaparkan bahwa kata pengantar yaitu memuat informasi tentang peran modul dalam proses pendampingan. Lalu perancangan yang ke tiga membuat daftar isi, daftar isi berisikan pokok- pokok materi yang ada dalam modul di sertai nomor halam, sesuai kemunculan pada saat membuka modul. Selaras dengan yang dikemukakan oleh (Departemen Pendidikan Nasional, 2008) bahwa daftar isi menyajikan topik-topik yang dibahas yang diurutkan berdasarkan urutan kemunculan dalam modul. Pendamping dapat melihat secara keseluruhan, topiktopik apa saja yang tersedia dalam modul. Daftar isi juga mencantumkan nomor halaman untuk memudahkan pembelajar menemukan topik.

Perancangan bagian isi yaitu perancangan pertama membuat deskripsi ringkasan, deskripsi ringkasan berisikan penjelasan secara singkat tentang latar belakang pembuatan modul, masalah yang dihadapi lansia dan pendamping, fungsi dari modul dan program yang dirancang. Hal ini selaras dengan yang dikemukakan Rahdiyanta (2009) bahwa deskripsi ringkasan yaitu penjelasan singkat tentang ruang lingkup isi modul. Perancangan ke dua membuat tujuan, tujuan mencakup tujuan umum dan tujuan khusus. Tujuan umum yaitu bertujuan sebagai sumber belajar dalam melaksanakna pendampingan, sedangkan tujuan khusus yaitu kemampuan-kemampuan yang harus dimiliki oleh pendamping. Rahdiyanta (2009) menyatakan bahwa tujuan merupakan kemampuan-kemampuan yang harus dikuasai oleh pendamping dalam kegiatan pendampingan. Perancangan yang ke tiga membuat pokok materi/ bahasan, pokok materi yaitu berisikan sub judul materi yang akan dibahas pada uraian materi. Perancangan yang ke empat membuat uraian materi, uraian materi yaitu pembahasan yang lebih terperinci dan jelas, mengenai sub judul yang telah di paparkan pada pokok materi.

Pada uraian materi di buat semenarik mungkin seperti di tambahkan foto yang menggambarkan materi yang diuraikan, di tambahkan desain-desain agar tidak membuat pendamping pada saat membaca bosan. Hal ini selaras dengan Departemen Pendidikan Nasional (2008) bahwa uraian materi merupakan penjelasan secara terperinci tentang materi pembelajaran yang disampaikan dalam modul. Perancangan yang ke lima membuat metode pendampingan, metode pendampingan berisikan cara tepat yang dapat dilakukan pendamping dalam melakukan pendampingan kepada lansia. Perancangan yang ke enam membuat prinsip pendampingan, prinsip pendampingan yaitu panduan dalam melaksanakan pendampingan, yang harus diketahui dan dilakukan oleh pendamping. Perancangan yang ke tujuh membuat alat bantu, alat bantu berisi alat-alat yang dapat digunakan dalam pendampingan setra media yang tepat dalam proses pendampingan. Lalu yang terakhir perancangan evaluasi pendampingan, evaluasi pendampingan yaitu alat penilaian yang dilakukan untuk mengetahui hasil dari pelayanan pendampingan yang telah dilakukan.

Perancangan bagian penutup yaitu perancangan pertama membuat rangkuman, rangkuman yaitu Rangkuman berisi uraian materi yang panjang menjadi lebih singkat, padat, dan jelas tanpa mengabaikan ide pokok dari uraian yang tertera dalam materi. Departemen Pendidikan Nasional (2008) mengemukakan bahwa rangkuman merupakan bagian dalam modul yang menelaah hal-hal pokok dalam modul yang telah dibahas. Rangkuman diletakkan pada bagian akhir modul. Perancangan yang ke dua yaitu daftar pustaka, daftar pustaka berisikan kumpulan rujukan pada saat penulisan modul. Rahdiyanta (2009) menyatakan bahwa semua referensi/pustaka yang digunakan sebagai acuan pada saat penyusunan modul.

Validasi modul pendampingan perawatan kesehatan mental lanjut usia berbasis home care yang dilakukan oleh ahli modul/media dan ahli pelayanan lansia, bertujuan untuk memberikan penilaian terhadap modul yang dirancang. Dilakukannya penilaian agar mengetahui modul yang dirancang layak atau tidak layak. Departemen Pendidikan Nasional (2008) menyatakan bahwa validasi adalah proses permintaan persetujuan atau pengesahan terhadap kesesuaian modul dengan kebutuhan. Untuk mendapatkan pengakuan kesesuaian tersebut, maka validasi perlu dilakukan dengan melibatkan pihak praktisi yang ahli sesuai dengan bidang-bidang terkait dalam modul.

Jurnal Kesejahteraan Keluarga dan Pendidikan [JKKP] Vol.06 No.01 doi.org/10.21009/JKKP.061.02 
Aspek kelayakan modul berada pada kriteria sangat layak untuk digunakan berdasarkan hasil validasi yang dilakukan oleh ahli modul/media. Aspek yang divalidasi oleh ahli modul/media adalah aspek kelayakan modul yang terdiri dari tiga indikator penilaian yaitu kesesuaian bagian pembuka, bagian isi, dan bagian penutup.

Aspek kelayakan isi berada pada kriteria sangat layak digunakan berdasarkan hasil validasi yang dilakukan oleh ahli pelayanan lansia.

\section{KESIMPULAN}

Modul pendampingan lanjut usia berbasis home care dalam perawatan kesehatan mental dirancang berdasarkan analisis kebutuhan pendamping dan karakteristik lansia. Perancangan modul pendampingan lanjut usia berbasis home care dalam perawatan kesehatan mental dirancang merujuk pada analisis kebutuhan dan dalam penulisan modul mengacu pada komponen modul yang harus dikembangkan. Bagian pembuka terdiri dari cover, kata pengantar dan daftar isi. Cover yang dibuat semenarik mungkin seperti dalam warna dan gambar yang digunakan agar pendamping merasa tertarik saat membaca dan dapat menggambarkan isi modul. Komponen yang ke dua yaitu bagian isi, pada bagian isi terdiri dari deskripsi ringkasan, tujuan, pokok bahasan uraian materi, metode pendampingan, alat bantu dan evaluasi. Deskripsi ringkasan berisi tentang penjelasan singkat isi modul. Komponen yang ketiga yaitu bagian penutup, bagian penutup terdiri dari rangkuman yaitu ringkasan dari materi yang telah diuraikan dan daftar pustaka berisi sumber rujukan pada saat penulisan. Hasil validasi modul pendampingan lanjut usia berbasis home care dalam perawatan kesehatan mental, dinyatakan sangat layak baik dari aspek kelayakan modul dan aspek kelayakan isi. Aspek kelayakan modul dilihat dari kesesuaian bagian pembuka, bagian isi dan bagian penutup. Kelayakan materi dilihat dari kelengkapan materi. Maka modul pendampingan perawatan kesehatan mental lanjut usia dapat diimplementasikan. Produk yang dihasilkan dari penelitian ini berupa modul pendampingan lanjut usia berbasis home care dalam perawatan kesehatan mental. Modul ini dapat dijadikan sebagai sumber belajar dan menjadi bahan acuan dalam proses pendampingan khususnya dalam perawatan kesehatan mental lanjut usia.

\section{DAFTAR PUSTAKA}

Azizah, L. M. (2011). Keperawatan Lanjut Usia. Yogyakarta: Graha IImu.

Departemen Pendidikan Nasional. (2008). Penulisan Modul. Kompetensi dan Pengembangan 05-A2. Jakarta: Depdiknas.

Kemenkes. (2016). PMK No.25 Tentang Rencana Aksi Nasional Lanjut Usia Tahun 2016-2019, 96.

Kementerian Sosial RI. (2014). Modul pendampingan pelayanan sosial lanjut usia.

Kusumowardani, A., \& Puspitosari, A. (2010). Hubungan Antara Tingkat Depresi Lansia dengan Interaksi Sosial Lansia Di Desa Sobokerto Kecamatan Ngemplak Boyolali, 184-188.

Nurfatimah, R., Rifa'i, M. S. S., \& Jubaedah, Y. (2017). Perancangan Program Pendampingan Lanjut Usia Berbasis Home care Di Posbindu Kelurahan Geger Kalong, III(2).

Parmin, \& Peniati, E. (2012). Pengembangan Modul Mata Kuliah Strategi Belajar Mengajar Ipa Berbasis Hasil Penelitian Pembelajaran. Jurnal Pendidikan IPA Indonesia, 1(1), 8-15.

Rahdiyanta, D. (2009). Teknik penyusunan modul, 1-14.

Riani, S., Adi, H., \& Supriyono, M. (2010). Studi Deskripsi Status Mental Lansia Berdasarkan Karakteristik Lansia Di Kelurahan Karangayu Semarang Barat, 129, 1-9.

Tati, Rinekasari, N. R., \& Jubaedah, Y. (2017). Model Pendampingan Lanjut Usia Berbasis Home care dalam Implementasi Pendidikan Vokasional, 5(2), 74-86.

Widyakusuma, Nurnita. (2013). Peran Pendamping Dalam Program Pendampingan dan Perawatan Sosial Lanjut Usia di Lingkungan Keluarga (Home care): Studi Tentang Pendampingan di Yayasan Fitrah Sejahtera, Keluarahan Cilincing, Kecamatan Cilincing Jakarta Utara. Pusat Pendidikan dan Pelatihan Kementerian Sosial RI. 